\title{
CORRELATING FOLIAR NITROGEN LEVELS WITH GROWTH IN TWO LANDSCAPE TREE SPECIES
}

\author{
by Ed Perry and Gary W. Hickman
}

\begin{abstract}
Trials were conducted to determine the effect of applied soluble nitrogen fertilizer on leaf nitrogen concentrations and growth in valley oak (Quercus lobata) and Chinese pistache (Pistacia chinensis) trees. Leaf nitrogen concentrations in valley oak were not significantly affected by the fertilizer at $3,9,16$, and 28 months following treatment. Leaf nitrogen concentrations in Chinese pistache were not significantly affected by the fertilizer at 9 and 12 months following treatment. The fertilizer treatments did not cause increases in trunk diameter growth in either species over the period of the study. Additionally, no correlation could be made between visual nitrogen deficiency symptoms and actual leaf nitrogen concentrations.
\end{abstract}

Keywords. Nitrogen fertilization; ornamental tree nutrition; leaf analysis; Quercus lobata; Pistacia chinensis.

Fertilization of landscape trees continues to be a poorly understood cultural practice. Throughout much of the United States, where most woody plants respond only to supplemental nitrogen, nitrogen-containing fertilizers are often applied on the basis of visual symptoms, or annually as "insurance," rather than on the basis of need. The practice is justified by the relatively low cost of purchasing and applying nitrogen-containing fertilizers. However, applying nutrients without knowing they are deficient is a waste of time and money and can lead to excessive soil salts and water pollution (Harris 1992). McClure (1991) reports that certain sucking pests are favored by excessive nitrogen fertilization.

Relying upon visual symptoms alone to diagnose nitrogen deficiencies may lead to unnecessary fertilizer use, considering the difficulty of accurate visual diagnosis. Smith (1978) states that anything which restricts root growth-such as soil diseases, insects, root pruning, soil compaction, adverse soil temperatures, low oxygen, and poor drainage-may reduce nutrient uptake. Such root problems may produce symptoms, including chlorotic leaves, smaller and fewer leaves, and reduced shoot growth, all of which resemble nitrogen deficiencies.
Leaf tissue analysis is a quantitative method for detecting nutrient deficiencies and evaluating fertilizer programs but is seldom used by arborists and landscape managers. It has been used for years by tree fruit producers as a guide for determining nutrient deficiencies and timing of fertilizer applications. Critical nutrient levels have been established for most major fruit tree crops (Childers 1966; Reisenauer 1983) and for a number of woody ornamental species grown as container nursery stock (Smith 1972). In the Netherlands, Kopinga and van den Burg (1995) report that chemical leaf analysis has become more important than soil analysis in studies on the supply of nutrient elements to trees; they also report values for tissue content of nitrogen, phosphorus, potassium, and magnesium of 48 landscape tree species. Similar values are not currently available for most landscape tree species in the United States, although the need for such information is expressed by Smiley (1994), who states that without standard foliar nutrient values for healthy landscape plants, it is difficult to determine if trees or shrubs are at the "hidden hunger nutrient level."

As concerns about excessive fertilizer use increase, leaf analysis may become a more common management practice. Smith (1978) reports that in landscape plant culture, plant tissue analysis has become a valuable tool in identifying mineral deficiencies and in designing an efficient fertilization program. Harris (1992) states that we must document more correlation among tissue analysis, plant symptoms, and fertilizer responses before meaningful standards can be developed for determining the nutrient status and needs of woody landscape plants.

The main objective of this trial was to correlate the growth of valley oak (Quercus lobata) and Chinese pistache (Pistacia chinensis) trees with the nitrogen content of leaf tissue following ap- 
plications of a soluble nitrogen fertilizer. An additional objective was to determine if a correlation exists between chlorosis, poor shoot growth, and foliar nitrogen concentrations.

\section{Materials and Methods}

Thirty valley oak trees were used for the oak tree component of this study. The trees were 5

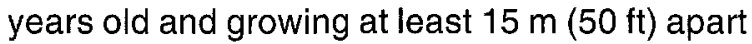
in a nonturfed park area in the city of Modesto, California. The average trunk dbh (diameter at breast height) of the trees at the beginning of the test was $10.9 \mathrm{~cm}$ (4.3 in.). Trunk diameter measurement is a reliable method for determining growth responses, and it is strongly correlated to overall shoot growth in deciduous trees (Khatamian and Hilton 1997). The soil type was a Bear Creek clay loam, classified by the soil survey as moderate in natural fertility (Arkley 1964) and typical of soils developed as parks in the Central Valley of California. The soil was uniform throughout the area of the trial. Four soil samples from surface to $0.6 \mathrm{~m}(2 \mathrm{ft})$ deep and

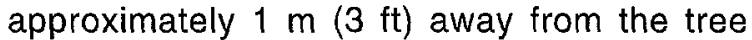
trunks were collected on April 12, 1993, and a composite sample was submitted to the University of California Division of Agriculture and Natural Resources Analytical Laboratory for analysis of nitrogen content. The analysis indicated a total nitrogen content of $0.051 \%$.

Treatments consisted of applications of ammonium nitrate (34-0-0) at $0.1 \mathrm{~kg}$ of actual nitrogen per $2.5 \mathrm{~cm}$ (0.25 lb N per in.) dbh, ammonium nitrate at $0.2 \mathrm{~kg}$ of actual nitrogen per $2.5 \mathrm{~cm} \mathrm{dbh}$, and an unfertilized control. The fertilizer rates are those currently recommended by Lilly et al. (1993). There were 10 replications (trees) per treatment, in a complete randomized block design. The fertilizer was broadcast on the soil surface in a $25 \mathrm{~m}^{2}\left(269 \mathrm{ft}^{2}\right)$ area beneath each tree. Treatments were made January 19, 1994. A rainfall amount of $1.9 \mathrm{~cm}$ (0.75 in.) was recorded in the trial area on January 25,1994 . Total rainfall during the trial period was $75.9 \mathrm{~cm}$ (29.9 in.). Annual amounts were $23.3 \mathrm{~cm}$ (9.2 in.) for 1994, $29.5 \mathrm{~cm}$ (11.6 in.) for 1995, and $23.1 \mathrm{~cm}$ (9.1 in.) for 1996. No supplemental irrigation was applied during the trial.
To determine the effect of the applied nitrogen on levels of total nitrogen in tree leaves, samples were taken throughout the duration of the trial. Leaf samples were collected 3 months after treatment, 9 months after treatment, 16 months after treatment, and at the conclusion of the study 28 months after treatment. Approximately 50 leaves were collected at random from throughout the lower to mid-crown of each tree; leaf samples consisted of the most recently matured leaves near the shoot tips on the current season's growth (Harris et al. 1977). To determine the effect of the fertilizer treatments on tree growth, trunk dbh measurements were taken at the start and conclusion of the trial.

A total of 16 trees within the test area were used to determine if a correlation existed between visual nitrogen deficiency symptoms and actual leaf nitrogen concentration. Khatamian et al. (1984) state that trees with high foliar nitrogen concentrations appear greener than those with a lower foliar nitrogen content. Nitrogen-deficient trees have low vigor characterized by uniformly yellowish green leaves and short shoot growth (Harris 1977; Smith 1978). Based on those symptoms, each of the 16 trees was assigned to 1 of 4 vigor groups, using the vigor component of a rating system developed for oak tree hazard evaluations (Hickman et al. 1989). Group 1 included trees of excellent vigor (foliage deep green, annual shoot growth exceeding 6 in.). Group 2 included trees with good vigor (foliage deep green, annual shoot growth less than 6 in.). Group 3 included trees with fair vigor (foliage yellowish green, annual shoot growth less than 6 in.). Group 4 trees had poor vigor (foliage yellow, little or no annual shoot growth). Due to the difficulty of identifying large numbers of trees for each vigor group, particularly in vigor groups 3 and 4 , each group consisted of only 4 trees. Using the same sampling method as described earlier, leaf samples were taken from each tree in each of the 4 groups and submitted to the laboratory for analysis of total nitrogen. Ratings and leaf sampling were done on September 19, 1996, at the end of the growing season.

Ten Chinese pistache trees were used for the 2nd component of the study. The trees were grow- 


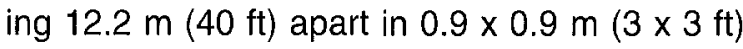
sidewalk cutouts in the city of Manteca, California. The trees were transplanted from 57-L (15gal) containers on July 6, 1995, and received no fertilization at time of planting. Polyethylene root barriers $56 \times 56 \times 46 \mathrm{~cm}$ deep $(22.1 \times 22.1 \times 18$ in.) were installed around each tree at the time of planting. The average dbh of the trees at the beginning of the trial was $2.85 \mathrm{~cm}$ (1.13 in.). The trees were irrigated at full evapotranspiration (water lost by transpiration from plants and evaporation from the soil) of $119.4 \mathrm{~cm}$ (47 in.), using a drip system. Total rainfall during the trial period was $42.7 \mathrm{~cm}$ (16.8 in.). The soil type was a Delhi loamy sand, classified by the soil survey as fair in natural fertility (McElhiney 1992). Four soil samples from surface to $0.6 \mathrm{~m}(2 \mathrm{ft})$ deep were collected from the site on July 11,1995, and a composite sample was submitted to the University of California Analytical Laboratory for analysis of nitrogen content. The analysis indicated a total soil nitrogen content of $0.1 \%$.

Leaf samples were also taken at the start of the trial to establish a baseline level for total nitrogen in leaf tissue. The analysis indicated an average total leaf nitrogen content of $1.9 \%$ in all trees.

Fertilizer treatments consisted of applications of ammonium sulfate (21-0-0) at $1.8 \mathrm{~kg}$ of actual nitrogen per $93 \mathrm{~m}^{2}$ (4 lbs N per $\left.1,000 \mathrm{ft}^{2}\right)$ and an unfertilized control. The amount of fertilizer used represents the high rate currently recommended by the International Society of Arboriculture (Lilly et al. 1993). There were 5 replications (trees) per treatment, in a complete randomized block design. The fertilizer was broadcast on the soil surface within the root barrier area beneath the trees. Treatments were made July 12,1995 . Irrigation water was applied within 24 hours of the treatments. To determine the effect of the fertilizer treatments on tree growth, trunk dbh measurements were taken at the start and conclusion of the trial.

Twelve Chinese pistache trees were used to test the correlation between visual nitrogen deficiency symptoms (low vigor characterized by chlorotic leaves and shoot growth) and actual leaf nitrogen concentration. The trees were growing in a turfgrass area in a Stockton, California, city park. The soil type in the area is a Stockton adobe clay, classified by the soil survey as good in natural fertility (McElhiney 1992). Using the same rating system as described for the oak trees, each of the 12 pistache trees was assigned to 1 of 4 vigor groups, with 3 trees assigned to each group. Approximately 50 leaves were collected at random from throughout the lower to mid-crown of each tree; leaf samples consisted of the most recently matured leaves near the shoot tips on the current season's growth. The samples were submitted to the laboratory for analysis of total nitrogen. Ratings and leaf sampling were done on May 8, 1997.

\section{Results and Discussion}

Concentrations of total nitrogen (percentage of dry weight) in oak leaf tissues were not affected by the nitrogen fertilizer during the period of the trial (Table 1). Neither low nor high rates of ammonium nitrate caused increases in foliar nitrogen levels in treated trees compared to untreated trees.

Growth of the oak trees in this 24-month trial was not improved by an application of a soluble nitrogen fertilizer (Table 2). There was an increase in tree size within all 3 treatments over the trial period. The trees fertilized with the low rate of nitrogen grew from $10.9 \mathrm{~cm}(4.3 \mathrm{in}$.) to $15.1 \mathrm{~cm}$

Table 1. Percentage concentration of total nitrogen in oak leaf tissue following fertilizer applications.

\begin{tabular}{lcccc}
\hline & \multicolumn{4}{c}{ Months after application } \\
\cline { 2 - 5 } Treatment & 3 & 9 & 16 & 28 \\
\hline $0.2 \mathrm{~kg} \mathrm{~N} / 2.5 \mathrm{~cm} \mathrm{dbh}^{\mathrm{a}}$ & 3.4 & 2.2 & 2.8 & 2.9 \\
$0.1 \mathrm{~kg} \mathrm{~N} / 2.5 \mathrm{~cm} \mathrm{dbh}{ }^{\mathrm{b}}$ & 3.0 & 2.3 & 2.8 & 2.8 \\
Control & 3.1 & 2.4 & 2.8 & 2.7 \\
\hline
\end{tabular}

${ }^{\mathrm{a}} 0.50 \mathrm{lb} \mathrm{N} / \mathrm{in} . \mathrm{d} \mathrm{bh}$

${ }^{\mathrm{b}} 0.25 \mathrm{lb} \mathrm{N} / \mathrm{in}$. dbh.

Table 2. Effect of nitrogen fertilization on oak trunk diameter after 16 months.

\begin{tabular}{lc}
\hline Treatment & Dbh $(\mathrm{cm})$ \\
\hline $0.2 \mathrm{~kg} \mathrm{~N} / 2.5 \mathrm{~cm} \mathrm{dbh}$ & $14.9^{\mathrm{a}}$ \\
$0.1 \mathrm{~kg} \mathrm{~N} / 2.5 \mathrm{~cm} \mathrm{dbh}$ & 15.1 \\
Control & 15.7 \\
\hline a $0.50 \mathrm{lb} \mathrm{N} / \mathrm{in} . \mathrm{dbh}$. & \\
${ }^{\mathrm{b}} 0.25 \mathrm{lb} \mathrm{N} / \mathrm{in} . \mathrm{dbh}$. & \\
${ }^{\mathrm{C}}$ Treatment differences were not significant at $5 \%$ level (DMRT).
\end{tabular}


(5.9 in.) dbh. Trees fertilized with the high rate grew from $11.1 \mathrm{~cm}(4.4 \mathrm{in}$.) to $14.9 \mathrm{~cm}$ (5.8 in.) $\mathrm{dbh}$. Control trees grew from $10.5 \mathrm{~cm}(4.1 \mathrm{in}$.) to $15.7 \mathrm{~cm}$ (6.2 in.) dbh.

Because the nitrogen fertilizer did not affect either foliar nitrogen concentrations or tree diameter growth, no correlation between leaf analyses and measured growth could be made from this trial. From these data, it appears that the native fertility of the soil at the growing site was adequate, as unfertilized trees had foliar nitrogen concentrations equal to fertilized trees. According to previous studies, leaf nitrogen concentrations in the range of 2.0 and above are adequate for oak. Kopinga and van den Burg (1995) reported leaf nitrogen levels of less than $1.8 \%$ as too low, and $2.1 \%$ to $2.8 \%$ as normal for pin oak (Quercus palustris) and English oak ( $Q$. robur). In a study of fertilizer application techniques, Smiley et al. (1991) found nitrogen concentrations in willow oak ( $Q$. phellos) foliage deficient at $1.4 \%$ and adequate at $2.0 \%$. In the current study, the average concentration of foliar nitrogen from trees of excellent to poor vigor was $2.4 \%$, well within the published adequate range.

Trees that exhibited excellent vigor did not have significantly higher leaf nitrogen levels than trees with good, fair, or poor vigor (Table 3). Problems other than nitrogen deficiency, such as root disorders, inadequate irrigation, etc., apparently caused the yellow foliage and poor growth in the trees exhibiting fair and poor vigor. These results question the reliability of using visual symptoms alone for determining nitrogen deficiency in valley oak trees.

Results of the Chinese pistache study were similar to the oak study in most respects. Concentrations of total nitrogen in pistache leaf tissues and trunk diameter growth were not affected

Table 3. Visual nitrogen deficiency symptoms (vigor) compared to actual leaf nitrogen concentration in oak.

\begin{tabular}{|c|c|}
\hline Vigor group & Percentage total $\mathrm{N}$ \\
\hline 1-Excellent & $2.5^{\mathrm{a}}$ \\
\hline 2-Good & 2.3 \\
\hline 3-Fair & 2.3 \\
\hline 4-Poor & 2.3 \\
\hline
\end{tabular}

by the nitrogen fertilizer during the period of the trial (Table 4). Also, growth of the trees was not improved by an application of a soluble nitrogen fertilizer (Table 5). There was an increase in tree size within both treatments over the trial period. For the control trees, average trunk dbh increased from 2.8 to $4.2 \mathrm{~cm}$ (1.1 to $1.7 \mathrm{in}$.). For the fertilized trees, average trunk dbh increased from 2.9 to $3.9 \mathrm{~cm}$ (1.1 to $1.5 \mathrm{in}$.).

Because the nitrogen fertilizer did not affect foliar nitrogen concentrations and tree diameter growth, no correlation between leaf analyses and measured growth could be made from this trial. As with the valley oak, it appears that the native fertility of the soil at the growing site was adequate because nonfertilized Chinese pistache trees had foliar nitrogen concentrations and grew as well as fertilized trees. Unlike oak, there are no published critical levels for nitrogen in Chinese pistache leaves.

Nitrogen levels of pistache trees with excellent vigor were not significantly different from trees with good to poor vigor (Table 6). As with oak,

Table 4. Percentage concentration of total nitrogen in Chinese pistache leaf tissue at intervals following fertilizer applications.

\begin{tabular}{lcc}
\hline & \multicolumn{2}{c}{ Months after treatment } \\
\cline { 2 - 3 } Treatment & 9 & 12 \\
\hline $1.8 \mathrm{~kg} \mathrm{~N} / 93 \mathrm{~m}^{2^{\mathrm{a}}}$ & 3.0 & 2.0 \\
Control & 2.8 & 2.0 \\
\hline $\mathrm{a}_{4} \mathrm{lb} \mathrm{N} / 1,000 \mathrm{ft}^{2}$ & & \\
\hline
\end{tabular}

Table 5. Effect of nitrogen fertilization on Chinese pistache trunk diameter after 15 months.

\begin{tabular}{lc}
\hline Treatment & Dbh $(\mathrm{cm})$ \\
\hline $1.8 \mathrm{~kg} \mathrm{~N} / 93 \mathrm{~m}^{2^{\mathrm{a}}}$ & $3.9^{\mathrm{b}}$ \\
Control & 4.2 \\
$\mathrm{a}^{\mathrm{a}} \mathrm{lb} \mathrm{N} / 1,000 \mathrm{ft}^{2}$. & \\
${ }^{T}$ Treatment differences were not significant at $5 \%$ level (DMRT).
\end{tabular}

Table 6. Visual nitrogen deficiency symptoms (vigor) compared to actual leaf nitrogen concentration in Chinese pistache.

\begin{tabular}{lc}
\hline Vigor group & Percentage total N \\
\hline 1-Excellent & $2.0^{\mathrm{a}}$ \\
2-Good & 1.9 \\
3-Fair & 2.0 \\
4-Poor & 1.7 \\
TTreatment differences were not significant at 5\% level (DMRT).
\end{tabular}


factors other than nitrogen deficiency were apparently responsible for the low pistache tree vigor. More research is needed to establish critical ranges for Chinese pistache and other commonly used landscape trees.

It can be concluded from these trials that for valley oak and Chinese pistache, leaf nitrogen levels do not correlate with visual nitrogen deficiency symptoms. These findings call into question the practice of using visual symptoms alone as a reliable method of diagnosing nitrogen deficiency. A second conclusion is that for the same 2 species, adding nitrogen did not change leaf nitrogen levels or diameter trunk growth.

\section{Literature Cited}

Arkley, R.J. 1964. Soil Survey, Eastern Stanislaus County, California. USDA Soil Conserv. Ser. Superintendent of Documents, Washington, DC.

Childers, N.F. (Ed.). (2nd. ed.).1966. Nutrition of Fruit Crops: Temperate, Subtropical, Tropical. Horticultural Publications, New Brunswick, NJ.

Harris, R.W. 1992. Root-shoot ratios. J. Arboric. 18(1):39-42.

Harris, R.W., J.L. Paul, and A.T. Leiser. 1977. Fertilizing Woody Plants. Univ. Calif. Agr. Sci. Leaflet 2958.

Hickman, G.W., J. Caprille, and E. Perry. 1989. Oak tree hazard evaluation. J. Arboric. 15(8):177-184.

Khatamian, H., and R.J. Hilton. 1977. The relationship between shoot growth and area of trunk crosssection in several woody plant species. HortScience 12(3):255-257.

Khatamian, H., J.C. Pair, and R. Carrow. 1984. Effects of trunk competition and fertilizer application on trunk diameter and nutrient composition of honeylocust. J. Arboric. 10(5):156-159.

Kopinga, J., and J. van den Burg. 1995. Using soil and foliar analysis to diagnose the nutritional status of urban trees. J. Arboric. 21(1):7-24.

Lilly, S.J. et al. 1993. Tree nutrition and fertilization, pp 5.1-5.8. Arborists' Certification Study Guide. International Society of Arboriculture. Savoy, IL.

McClure, M.S. 1991. Nitrogen fertilization of hemlock increases susceptibility to hemlock woolly adelgid. J. Arboric. 17(8):227-229.

McElhiney, M. (Ed.). 1992. Soil Survey of San Joaquin County, California. USDA Soil Conserv. Serv. Superintendent of Documents, Washington, DC.

Reisenauer, H.M. (Ed.). 1983. Soil and Plant Tissue Testing in California. Univ. Calif. Agr. Sci. Bull. 1879.
Smiley, E.T., B.R. Fraedrich, and D.C. Booth. 1991. Comparison of trunk injected and soil applied macronutrients. J. Arboric. 17:322-324.

Smiley, E.T. 1994. Soil and tissue testing: Analyze before you fertilize. Arbor Age. 14(4):20-23.

Smith, E.M. 1972. A survey of foliar mineral element content of nursery-grown ornamentals. HortScience 7(3), Sec. 2:321.

Smith, E.M. 1978. Fertilizing trees and shrubs in the landscape. J. Arboric. 4(7):11-15.

Farm Advisors

University of California

Cooperative Extension

733 County Center III

Modesto, CA 95355

Résumé. Des recherches ont été menés pour déterminer l'effet de l'application d'azote soluble sur les concentrations en azote foliaire et la croissance du chêne blanc de Californie (Quercus lobata) et du pistachier de Chine (Pistacia chinensis). Les concentrations en azote foliaire chez le chêne blanc n'ont pas été modifiées significativement par l'engrais à $3,9,16$ et 28 mois d'intervalles après le traitement. Les concentrations en azote foliaire n'ont pas été modifiées significativement par l'engrais à 9 et 12 mois après le traitement. L'engrais n'a pas provoqué d'augmentation de croissance dans le tronc des deux espèces durant la période couverte par l'étude. De plus, aucune corrélation n'a pu être établie entre des symptômes visuels de déficiences en azote et les concentrations réelles en azote foliaire.

Zusammenfassung. Um den Effekt von angewendeten Iöslichen Stickstoffdüngern auf die Blattstickstoffkonzentration und Wachstum von Eichen (Quercus lobata) und Chinesischen Pistazien (Pistacia chinensis) zu bestimmen, wurden Versuche unternommen. Die Blattstickstoffkonzentration der Eiche wurde in $3,9,16$ und 28 monatigen Intervallen nach der Behandlung nicht besonders beeinflußst. Bei der Chinesischen Pistazie zeigte sich nach 9 bzw. 12 Monaten kein signifikanter Unterschied. Die Düngerbehandlunger führten während des ganzen Studienzeitraums bei beiden Arten nicht zu einmem Zuwachs des Stammumfangs. Es konnte auch keine Korrelation zwischen sichtbaren Stickstoffmangelerscheinungen und aktuellen Blattstickstoffkonzentrationen festgestellet werden.

Resumen. Se llevaron a cabo ensayos con el fin de determinar el efecto de un fertilizante nitrogenado soluble sobre las concentraciones de nitrógeno en las hojas y el crecimiento en árboles de Roble blanco de California (Quercus lobata) y Pistache chino (Pistacia chinenesis). Las concentraciones de nitrógeno foliar en Pistache chino no fueron afectadas significativamente por el fertilizante a intervalos de 9 y 12 meses siguientes al tratamiento. Los tratamientos fertilizantes no incrementaron el crecimiento del diámetro del tronco en ninguna de las especies durante el período de estudio. Además, no hubo correlación entre los síntomas visuales de deficiencia de nitrógeno y las concentraciones reales de nitrógeno foliar. 